\title{
RECYCLING OF TYRES IN LITHUANIA - PROBLEMS AND POSSIBILITIES
}

Vytautas Karlavicius

Perkunas

Lithuania

Industry and transport have very large development all the world. Growth of production calls big increasing of quantity of not disintegratable wastes, which pollute environment for long time. One of these wastes are scrap tyres, large quantities of which are accumulated. The rate of growth of them directly depends on the level automobilization and in many countries on unsolved problems of scrap tyres utilisation.

Therefore in world we have accumulation of very large quantities used tyres. Of late years only in European Community countries every year accumulate about 2 million metric tons of scrap tyres.

The resembling threat of scrap tyres problem is promoted in Lithuania, because quantity of cars reached about 1 million. Government of the Republic of Lithuania made limitations for used tyres import, but import of used tyres is growing and scrap tyres problem still exists.

Car tyres is one of main rubber industrial products. All components after tyres wearing out maintain their characteristics and structure. Tyres steel cord did not change, because it has no contact with air and humidity; rubber of tyres includes admixtures, which prevent oxidation and ageing of rubber. Therefore it is purposive to recycle used tyres and obtain from them steel and rubber granules, which can be successfully used in following production.

Recycling of used car tyres is very important state and ecological problem solution. It can be successfully solved with organisation of scrap tyres processing and using obtained recycling products as raw materials for following manufacturing. The similar strategy is more and more used in countries of European Community: in 1990 year $50 \%$ of used tyres were thrown out to the land fills, it is foreseen, that in 2000 year full recycling would be achieved. 
The problem in Lithuania till 1990 year was not solved because:

a) there was low level enough of automobilization;

b) used tyres fit for restoration were restored and after second use was thrown out to the landfills;

c) a small quantity of them were shredded and used for floor covers producing.

In 1995 year Lithuanian regional environmental departments begin to hand in certificates for complectation, storage and recycling of used tyres to several enterprises in some districts. Now these enterprises make only complectation and storage, but problem of scrap tyres recycling and using of obtained recycling products in following manufacturing are not solved. Some of them have nice intentions to recycle collected scrap tyres, but financial difficulties did not let them to solve the tyres recycling problem practically.

There exist two main techniques for the calculation of accruing used tyre quantities: one is based on the number of vehicles and another is based on the tyre imports/exports balance.

\section{Technique I (based on vehicle numbers)}

Table 1: Number of road vehicles (at year end)

\begin{tabular}{|c|c|c|c|c|c|c|c|}
\hline Vehicle type & 1990 & 1991 & 1992 & 1993 & 1994 & 1995 & $\%^{1}$ \\
\hline \multicolumn{8}{|c|}{ PASSENGER TRANSPORT } \\
\hline Cars & 492978 & 530824 & 565320 & 597735 & 652810 & 718469 & 81,78 \\
\hline incl. private & 477911 & 510562 & 542516 & 575980 & 627105 & 685552 & 78,00 \\
\hline Buses & 15157 & 15627 & 16284 & 16339 & 17103 & 17052 & 1,94 \\
\hline inc. private & 414 & 563 & 930 & 1699 & 2967 & 5824 & 0.66 \\
\hline Trolley-buses & 550 & 563 & 548 & 535 & 532 & 532 & 0,06 \\
\hline \multicolumn{8}{|c|}{ GOODS TRANSPORT } \\
\hline $\mathrm{Cars}^{2}$ & 83035 & 84341 & 87321 & 89530 & 93593 & 101422 & 11,54 \\
\hline incl. private & 3383 & 3105 & 6537 & 14786 & 24105 & 37873 & 4.31 \\
\hline $\begin{array}{c}\text { Semi-trailer } \\
\text { trucks }\end{array}$ & 7752 & 7728 & 8911 & 9241 & 7467 & 7469 & 0,85 \\
\hline Trailers & 11836 & 12311 & 11469 & 11813 & 12810 & 9136 & 1,03 \\
\hline Semi-trailers & 11474 & 11969 & 11794 & 10952 & 10696 & 9119 & 1,04 \\
\hline Special vehicles ${ }^{3}$ & 30928 & 26850 & 24172 & 23677 & 22459 & 15346 & 1,75 \\
\hline Vehicles total & 653710 & 690213 & 725819 & 759822 & 817470 & 878545 & 100 \\
\hline
\end{tabular}

Source: : Lithuanian Department of Statistics.

${ }^{1}$ as compared with the total number of vehicles, $\%$.

${ }^{2}$ including pick-ups and vans with car chassis.

${ }^{3}$ including special-purpose cars. 
Fig. 1: Dynamics of vehicle numbers

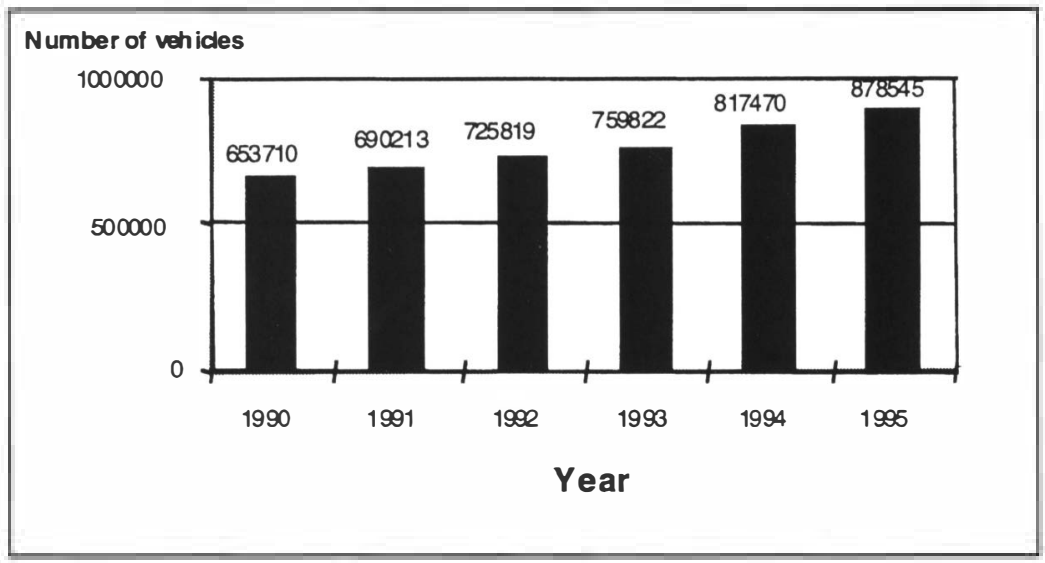

(1) Based on the data on the vehicle numbers in Lithuania, (2) taking into consideration the average tyre wear period and (3) taking into consideration the average tyre mass, forecasts of yearly and monthly quantities of tyres forming in Lithuania may be made.

Table 2: Quantities of used tyres formed in 1995

\begin{tabular}{|l|c|c|c|}
\hline & Cars & Other vehicles & Total \\
\hline Number of vehicles in 1995 & 718.469 & 160.076 & - \\
\hline Average number of tyres per vehicle & 4 & 6 & - \\
\hline Total number of tyres & 2.873 .876 & 960.456 & - \\
\hline $\begin{array}{l}\text { Intervals between tyre replacements, in } \\
\text { years }\end{array}$ & 4 & 5 & - \\
\hline Number of tyres replaced during a year & 718.469 & 192.091 & - \\
\hline Average tyre mass, kg & 7 & 50 & - \\
\hline Mass of tyres replaced annually, $t$ & $5.029,28$ & $9.604,56$ & $\mathbf{1 4 . 6 3 3 , 8 4}$ \\
\hline Mass of tyres replaced monthly, $t$ & 419,11 & 800,38 & $\mathbf{1 . 2 1 9 , 4 9}$ \\
\hline
\end{tabular}

As it is seen from Table 2, around 1,200 tons of used tyres had to accumulate in Lithuania monthly in 1995, and it is highly probable that the majority of them could be used for recycling. If such tyre quantities are collected monthly, this would exceed the enterprise's demand 1.9 times. The demand is 640 tons per month (running at a 100\% capacity, the monthly demand would be $700 \mathrm{t}$, how- 
ever, the plant will be operated at a $90 \%$ capacity, i.e. $640 \mathrm{t}$ of used tyres will be recycled).

\section{Technique II (based on tyre imports/exports)}

With a knowledge of the volumes of tyre imports and exports, it is possible to calculate the quantities of tyres remaining in Lithuania, i.e. how many tyres are replaced and how many tyres are accumulated.

Table 3: Exports and imports of new tyres, ths. units

\begin{tabular}{|l|c|c|c|c|c|c|}
\hline & \multicolumn{3}{|c|}{1995} & \multicolumn{3}{c|}{1996} \\
\cline { 2 - 7 } & Exports & Imports & Difference & Exports & Imports & Difference \\
\hline Cars & 22,2 & 101,8 & $\mathbf{7 9 , 6}$ & 58,88 & 207,96 & $\mathbf{1 4 9 , 0 8}$ \\
\hline Buses & 7 & 138,8 & $\mathbf{1 3 1 , 8}$ & 21,96 & 64,44 & $\mathbf{4 2 , 4 8}$ \\
\hline Aviation & 0,2 & 12 & $\mathbf{1 1 , 8}$ & 0,02 & 8,92 & $\mathbf{8 , 8}$ \\
\hline $\begin{array}{l}\text { Agricultural and } \\
\text { other transport }\end{array}$ & 2,2 & 8 & $\mathbf{5 , 8}$ & 1,8 & 9,68 & $\mathbf{7 , 8 8}$ \\
\hline
\end{tabular}

Source: Lithuanian Department of Statistics.

Table 4: Exports and Imports of used tyres, ths. units

\begin{tabular}{||c|c|c|c|c|c|c|}
\hline \multirow{2}{*}{} & \multicolumn{3}{|c|}{1995} & \multicolumn{3}{c|}{1996} \\
\cline { 2 - 7 } & Exports & Imports & Difference & Exports & Imports & Difference \\
\hline Restored & 1 & 51 & $\mathbf{5 0}$ & 14,8 & 102 & $\mathbf{8 7 , 2}$ \\
Used & 7,2 & 210,2 & $\mathbf{2 0 3}$ & 30,4 & 237,6 & $\mathbf{2 0 7 , 2}$ \\
Total & $\mathbf{8 , 2}$ & $\mathbf{2 6 1 , 2}$ & $\underline{\mathbf{2 5 3}}$ & $\mathbf{4 5 , 2}$ & $\mathbf{3 3 9 , 6}$ & $\mathbf{2 9 4 , 4}$ \\
\hline
\end{tabular}

Source: Lithuanian Department of Statistics.

More tyres remained in Lithuania in 1996 as compared with 1995 (this is mainly connected with the increase in the numbers of car tyre imports). It is probable that this trend will persist during the next 5 years, because the numbers of vehicles are increasing in this country.

By assuming that (1) the average weight of a car tyre is $7 \mathrm{~kg},(2)$ the average tyre weight for other vehicles is $50 \mathrm{~kg}$, (3) $80 \%$ of imported used tyres are intended for cars and $20 \%$ - for other types of vehicles (in proportion to the share of a vehicle type in the overall number of vehicles) it is possible to calculate the total mass of tyres replaced in Lithuania in 1995 and 1996 - Table 5. 
Table 5: Quantities of tyres replaced in 1995 and 1996

\begin{tabular}{||l|c|c|c|c|c|c|}
\hline & \multicolumn{3}{|c|}{1995} & \multicolumn{3}{c|}{1996} \\
\cline { 2 - 7 } & Cars & $\begin{array}{c}\text { Other } \\
\text { vehicles }\end{array}$ & Total & Cars & $\begin{array}{c}\text { Other } \\
\text { vehicles }\end{array}$ & Total \\
\hline $\begin{array}{l}\text { Number of tyres re- } \\
\text { placed annually }\end{array}$ & 282.000 & 200.000 & - & 384.600 & 118.040 & - \\
\hline $\begin{array}{l}\text { Average tyre mass, } \\
\text { kg }\end{array}$ & 7 & 50 & - & 7 & 50 & - \\
\hline $\begin{array}{l}\text { Mass of tyres re- } \\
\text { placed annually, } t\end{array}$ & $1.974,00$ & $10.000,00$ & $\mathbf{1 1 . 9 7 4 , 0 0}$ & $2.692,20$ & $5.902,00$ & $\mathbf{8 . 5 9 4 , 2 0}$ \\
\hline $\begin{array}{l}\text { Mass of tyres re- } \\
\text { placed monthly, } t\end{array}$ & 164,50 & 833,33 & $\mathbf{9 9 7 , 8 3}$ & 224,35 & $\mathbf{4 9 1 , 8 3}$ & $\mathbf{7 1 6 , 1 8}$ \\
\hline
\end{tabular}

Based on the above data (though the data presented in Tables 2 and 5 do not coincide, since the first case rests on three empirical assumptions and the second case - on official statistics, which does not reflect all processes taking place in an economy) it is possible to assert that in 1995 around 1,000 tons of tyres were replaced monthly and in 1996 - around 700 tons. Thus, quantities of used tyres were accumulated that exceed the raw material needs of the enterprise.

The line to be introduced will recycle both used tyres and other rubber waste. Data on rubber waste in Lithuanian production enterprises in 1994-1995 is presented in Table 6.

Table 6: Rubber waste in Lithuanian production enterprises in 1994 and 1995

\begin{tabular}{|c|c|c|c|c|c|}
\hline \multirow{2}{*}{ Year } & \multirow{2}{*}{$\begin{array}{c}\text { Formed in } \\
\text { production, } \mathbf{t}\end{array}$} & \multicolumn{2}{|l|}{ Recycled, used for production } & \multicolumn{2}{c|}{ Destroyed or taken to dumps } \\
\cline { 3 - 6 } & & tons & $\%$ & tons & $\%$ \\
\hline 1994 & 2383 & 363 & 15 & 875 & 37 \\
\hline 1995 & 1106 & 7 & 1 & 695 & 63 \\
\hline
\end{tabular}

Source: Lithuanian Department of Statistics

This data does not embrace all possible sources of formation of rubber waste but it alone is sufficient to demonstrate a fact that only a very small part of rubber waste is recycled.

The available data shows that the supply of raw materials for the new recycling line will be sufficient. Furthermore, several additional factors support the estimation that sufficient supply will be ensured during the nearest 5 years:

- The enterprise will be able to use both newly forming resources of used tyres and the resources that have accumulated earlier. 
- Chart 1 shows a steady increase in the numbers of vehicles in Lithuania, which ensures the increase in the used tyre quantities.

- The deterioration of roads in Lithuania causes both the growth in the demand for new tyres and in the quantities of used tyres.

- Sufficient and steady supply of new tyres encourages users to buy new instead of restoring old tyres, therefore the time of tyre use is becoming shorter.

Therefore it is especially important to organise in Lithuania net for collection of scrap tyres and other undestroyable wastes and to recycle them for obtaining steel and rubber granules for following manufacturing.

Rubber crumble, granulates and powders have many applications and are widely used depending on their graininess.

Table 7: Rubber crumble applications

\begin{tabular}{|c|c|c|c|}
\hline \multirow[t]{2}{*}{ No. } & \multirow[t]{2}{*}{ Application } & \multicolumn{2}{|c|}{ Necessary particle size } \\
\hline & & $\mathbf{m} \mathbf{m}$ & mesh(ASTM)-inches \\
\hline 1. & Sports grounds & & \\
\hline 1.1 & Running tracks & $1.6-4$ & $12-5$ \\
\hline 1.2 . & Floor for playgrounds & $1.6-4$ & $12-5$ \\
\hline 1.3 . & Children playground components & $1.6-4 / 4-7$ & $12-5,5-1 / 4 "$ \\
\hline 1.4 & $\begin{array}{l}\text { Base for playing fields with synthetic grass } \\
\text { (Mixture with sand or broken stone) }\end{array}$ & & \\
\hline 2. & Carpet industry & $7-16 / 10-16$ & $1 / 4 "-5 / 8 ", 3 / 8 "-5 / 8 "$ \\
\hline 2.0 & Bottom layer of carpets & $0.6-2$ & $30-10$ \\
\hline 2.2 & Carpet impregnation (for car carpets) & $0-0.8 / 0.8-1.6$ & $0-20 / 20-12$ \\
\hline 3. & Brake shoes & $0-0.6 / 0-0.8$ & $0-30 / 0-20$ \\
\hline 4. & Rubber mixtures & & \\
\hline 4.0 & Shoe soles & $0.4-0.6 / 0-0.8$ & $40-30 / 0-20$ \\
\hline 4.2 & Floor coverings & $0.4-0.6 / 0-0.8$ & $40-30 / 0-20$ \\
\hline 5. & For hard tyres & $0-2$ & $0-70$ \\
\hline 6. & Asphalt modifiers & & \\
\hline 6.0 & Road building & $0-0.8$ & $0-20$ \\
\hline 6.2 . & Roof coatings & $0-0.8$ & $0-20$ \\
\hline 6.3 . & Railway crossings & $1.6-4$ & $12-5$ \\
\hline 7. & For underground irrigation pipings & $0-0.6$ & $0-30$ \\
\hline 8. & Coatings & $0-0.2 / 0-0.8$ & $0-70 / 0-20$ \\
\hline 9. & Putties & $0-0.6$ & $0-30$ \\
\hline 10. & Antivibratory insulation & $2-10$ & $10-3 / 8^{\prime \prime}$ \\
\hline 11. & Sealing mixtures & $0-0.6$ & $0-30$ \\
\hline 12. & Recovered (devulcanized) rubber & $0-0.6$ & $0-30$ \\
\hline 13. & Rubber crumb with activated surface & $0-0.8$ & $0-20$ \\
\hline 14. & Rubber-plastic mixtures (polyblends) & $0-0.6$ & $0-30$ \\
\hline 15. & Fuel from tyres & $<25,<50$ & $<1 ",<2 "$ \\
\hline
\end{tabular}

Table 7 demonstrates that rubber crumb has a very wide application. 
The prices for rubber granulate are presented in Table 8. (International Rubber Marketing Bureau's data).

Table 8: Rubber granulate prices

(International Rubber Marketing Bureaués data

\begin{tabular}{|c|c|}
\hline Fraction size, mm & Price, US\$/t \\
\hline 6,35 & 350 \\
\hline 2,00 & 400 \\
\hline 0,84 & 440 \\
\hline 0,42 & 500 \\
\hline 0,20 & 650 \\
\hline
\end{tabular}

The prices for rubber granulates based on the information received from the Russian factories - potential users of rubber granulate and raw rubber - are presented in Table 9.

Table 9: Rubber granulate prices (Russian factories' data)

\begin{tabular}{|c|c|}
\hline Fraction size, mm & Price, US\$/t \\
\hline \hline$<3,00$ & $150-350$ \\
\hline$<0,20$ & $400-500$ \\
\hline
\end{tabular}

The raw rubber price may reach US $\$ 1,500$ per ton.

Collection system must be organised according administrative division in the districts.

Recycling must be implemented in one factory of high capacity, spread out in strategically convenient place.

Scrap tyres recycling factory must be state or joint-stock company with state control shares packet.

That factory must obtain governmental many-sided supporting. 